\title{
ENTREPRENUERSHIP DALAM PERSPEKTIF ALQURAN DAN ETNOLOGI
}

\author{
Abdiansyah Linge \\ STAIN Gajah Putih Takengon Aceh Tengah \\ abdiansyahlinge@gmail.com \\ Upi Sopiah Ahmad \\ STAIN Gajah Putih Takengon Aceh Tengah \\ opisopiahahmad@gmail.com
}

\begin{abstract}
Alquran is a guidance of life for the people to get prosperity in the world and beyond, Alquran implement a concept to combine both of them. Economic activities is also studied in holy quran, where holy quran talk about teory and concept in economic system. One of studies that interest in this research that have corelation with enterpreneurship, as an eforts to develope human quality. Many of variable that influence behaviour of person to do economic activities one of them is culture. This research means to interest the people do enterpreneurship and to increase it by using Alquran as guidance.This study used a qualitative approach, with shades of library research (library Risearch). This study also aims to determine the Qur'anic concept of entreprenuership, as well as ethnology relation to the formation of a person's interest to behave entreprenuership. Patterned with qualitative research literature research can be concluded: the Qur'an has economic theories with the concept tijarah including entreprenuership. The concept and value of economic value contained in the Qur'an into the basic motivation of behavior entreprenuers Muslims, the Qur'an which emphasizes benefit of the people, justice that promotes ethical behavior in each business process, became the basic philosophy in conducting economic activities, including the activities entreprenuership. Second, the idea of the results of the concept of human thought and activity in the form of economic behavior contained in a culture that became hereditary behavior in public when adjusted to the economic value contained in the Qur'an will awaken the concept or theory about sharia entreprenuership.
\end{abstract}


Keywords: Entreprenuership, Qur'an, Ethnology

\section{A. Pendahuluan}

Ayat Alquran berbicara mengenai ekonomi (filantropi) dalam bentuk perintahNYA dalam konsep zakat, infaq, shadaqah, hibah dan konsep ekonomi lain seperti riba, jual beli, keadilan dan lain sebagainya, untuk menciptakan dan memelihara kemaslahatan hidup serta martabat kehormatan manusia, dan Allah SWT menciptakan syariat yang mengatur cara memanfaatkan harta dengan baik. Salah satu cara memanfaatkan harta adalah dengan melaksanakan konsep ekonomi Islam, hal ini terdapat dalam Alquran kemudian diperjelas oleh Allah dengan aktualisasi pada Nabi Muhammad SAW. Bila merujuk pada Alquran, terdapat suatu sistem ekonomi Islam dalam penerapan kegiatan ekonomi, seperti lebih mengutamakan kesempatan dan pendapatan (QS. Ali Imran: 108 dan At Taubah: 34), tidak menyetujui pemborosan (QS. Al Isra': 26), tidak menyetujui spekulasi serta praktekpraktek ketidak jujuran dan penipuan (QS. Huud: 85-86), dan Islam menghendaki semua bentuk kegiatan ekonomi dilakukan dengan usaha yang sah dan jujur serta dilandasi dengan iman dan iktikad yang baik. (QS. An Nisa: 29)

Kegiatan ekonomi secara umum dalam Alquran juga menjadi kajian dan dasar pengembangan keilmuan ekonomi Islam. Seperti pengungkapan kata tijarah, serta mekanisme atau regulasi ekonomi yang terdapat dalam Alquran. Alquran juga memotivasi umat untuk berperan dalam ekonomi. Dengan motivasi dan regulasi ekonomi yang terdapat dalam Alquran, ekonom Islam dapat menemukan dan merekayasa model ekonomi yang sesuai dengan Islam.

Entreprenuership atau yang juga dikenal dengan kewirausahaan, merupakan prilaku ekonomi untuk mengelola sumberdaya yang dimiliki dengan membuka pasar baru, mengembangkan produk, membuka lapangan kerja, dan pengembangan inovasi dan berfikir cerdas dalam kegiatan ekonomi. Tulisan ini mengkaji tentang konsep filosofis entreprenuership dalam perspektif Alquran yang menjadi konsep dasar pengembangan ekonomi Islam dan bagaimana konsep ini dapat memberdayakan masyarakat dalam kegiatan ekonomi. 
Aspek lain yang menjadi kajian dalam tulisan ini adalah aspek budaya. Budaya merupakan bagian dari pemikiran, akal budi atau adat istiadat. Secara tata bahasa, kebudayaan diturunkan dari kata budaya cenderung menunjuk pada pola pikir manusia. Pada era globalisasi saat ini prilaku manusia juga tidak terlepas dari budaya atau adat istiadat yang diyakini.

Prilaku keseharian manusia merupakan refleksi dari pengetahuan, sikap dan prilaku yang merupakan kebiasaan yang dimiliki dan diwariskan oleh anggota suatu masyarakat.Sehingga prilaku ekonomi juga dipengaruhi oleh nilai-nilai yang terdapat dalam suatu sistem sosial masyarakat. Kata lain, kegiatan ekonomi yang dilakukan masyarakat pada saat ini juga berkaitan erat dengan budaya yang dimiliki masing-masing individu.

Kajian ini menggunakan pendekatan kualitatif, dengan corak kepustakaan (library risearch) dan bertujuan untuk mengetahui konsep Alquran tentang entreprenuership, serta kaitan etnologi terhadap pembentukan atau meningkatkan minat seseorang berperilaku entreprenuership yang sesuai dengan Alquran.

\section{B. Pembahasan}

\section{Entreprenuership}

Secara umum pemahaman tentang entreprenuers berkaitan dengan memulai usaha bisnis. Namun, pada hakikatnya konsep entreprenuer berasal dari Prancis pada awal abad ke 17 Vdan 18. Dimana memiliki arti "undertakes" bukan "undertaker", yaitu perbuatan yang berkaitan berusaha dalam segala bidang untuk meningkatkan kesejahteraan ekonomi. (Suryana, 2013: 5) Pada abad ke 20 ini, ekonom mengaitkan konsep entreprenuer dengan definisi yang ditawarkan oleh Schumpeter, dimana dijelaskan bahwa entreprenuers adalah inovasi untuk menemukan cara yang kreatif dengan menggunakan modal ekonomi. Jadi fungsi interprenuer adalah orang yang mendobrak sistem ekonomi yang ada dengan memperkenalkan barang dan jasa yang baru, dengan menciptakan bentuk organisasi baru atau mengolah bahan baku baru. (Schumpeter dalam Suryana, 2013: 6).

Entreprenuershipadalah proses dinamis untuk menciptakan nilai tambah barang dan jasa serta kemakmuran. 
Tambahan nilai dan kemakmuran ini diciptakan oleh individu entreprenuer yang memiliki keberanian menanggung risiko, menghabiskan waktu serta menyediakan berbagai produk barang dan jasa.

Sejalan dengan perkembangan konsep entreprenuership, Drucker, mendefinisikan entreprenuership sebagai kemampuan untuk menciptakan sesuatu yang baru dan berbeda. Adapun Zimmerer mengungkapkan bahwa kewirausahaan merupakan proses penerapan kreativitas dan inovasi untuk memecahkan masalah dan mencari peluang yang dihadapi setiap orang dalam setiap hari.(Drucker, 1994).

Entrepreneur berasal dari bahasa Prancis yang berarti kontraktor. Asal katanya entreprenant yang berarti giat, mau berusaha, berani, penuh petualangan dan entreprendre yang berarti undertake. Istilah entrepreneur mulai dipergunakan dalam bahasa Inggris sejak tahun 1878, dan dipahami sebagai a contractor acting as intermediary between capital and labour. (Schumpeter dalam Suryana, 2013: 6).

Ekonomi merupakan salah satu ilmu sosial yang mempelajari aktivitas manusia yang berhubungan dengan produksi, distribusi, dan konsumsi terhadap barang dan jasa. Istilah "ekonomi" sendiri berasal dari bahasa Yunani, yaitu oĩ коৎ (oikos) yang berarti "keluarga, rumah tangga" dan vópos (nomos) yang berarti "peraturan, aturan, hukum". Secara garis besar, ekonomi diartikan sebagai "aturan rumah tangga" atau "manajemen rumah tangga." Sementara yang dimaksud dengan ahli ekonomi atau ekonom adalah orang menggunakan konsep ekonomi dan data dalam bekerja.

Entreprenuership merupakan disiplin ilmu yang mempelajari tentang nilai, kemampuan (ability) dan prilaku seseorang. Nilai merupakan motivasi yang mendorong seseorang untuk melakukan kegiatan ekonomi. Alquran merupakan nilai yang mendorong seseorang untuk melakukan sesuatu termasuk kegiatan ekonomi. Kemampuan merupakan knowladges atau skills seseorang yang diperoleh melalui pendidikan dan pengalaman. Nilai dan ability akan menentukan prilaku seseorang dalam melihat dan memanfaatkan peluang ekonomi (economicopportunity). (Suryana, 2013: 2)

Prilaku entreprenuership didorong oleh nilai yang 
diyakini seseorang. Istilah nilai dalam kehidupan sehari-hari sering diperbincangkan oleh masyarakat mengenai maksud, tujuan, penghayatan dan pelaksanaannya. Dalam Kamus Bahasa Indonesia disebutkan salah satu arti nilai adalah sifat-sifat yang penting atau hal-hal yang berguna bagi kemanusiaan, nilai tradisional yang dapat mendorong pembangunan, sesuatu yang menyempurnakan manusia sesuai dengan hakikatnya. (DEPDIKBUD, 783)

Secara garis besar nilai dalam dua bagian yaitu nilainilai murni (values of being) dan nilai-nilai memberi (values ofgiving). Nilai-nilai murni adalah nilai yang ada dalam diri manusia, kemudian berkembang menjadi perilaku dan cara memperlakukan orang lain, termasuk dalam katagori nilai ini: keberanian, cinta damai, keandalan diri, potensi, disiplin, tahu batas, kemanusiaan dan kesesuaian. Sedang nilai-nilai memberi adalah nilai yang diperaktekkan atau diberikan dan diterima sebanyak yang diberikan, yang masuk dalam nilai kelompok ini ialah setia, dipercaya, hormat, cinta, kasih sayang, peka, tidak egois, baik hati, ramah, adil dan murah hati. (El Mubarak, 2009: 7).

Kemampuan juga menjadi modal utama entreprenuers dalam mengembangkan usaha ekonomi, kemampuan yang dapat diperoleh melalui lembaga pendidikan dan pengalaman hidup sehari-hari menjadi modal yang penting. Manusia diciptakan Allah dalam bentuk yang sempurna (QS. At Tiin: 4), dengan terus menerus mengambangkan diri dengan pedidikan dan ilmu pengetahuan akan membentuk seorang entreprenuers yang mampu mengelola vanture atau usaha ekonomi yang dikembangkan. Entreprenuership bukan hanya bakat yang dibawa sejak lahir atau urusan pengalaman di lapangan, tetapi juga dipelajari dan diajarkan.

Entreprenuership merupakan disiplin ilmu tersendiri yang independen karena memiliki karakteristik meliputi halhal berikut:

a. Merupakan bidang pengetahuan (body of knowladge), terdiri dari teori, konsep dan metode ilmiah

b. Memiliki dua konsep; Venture start-up dan venture growth

c. Objek kajian tersendiri, yaitu kemampuan menciptakan sesuatu yang baru dan berbeda (ability to create new and different things) 
d. Entreprenuership membuka lapangan kerja. Alat untuk menciptakan pemerataan usaha dan pendapatan atau kesejahteraan.(Prawirakusumo, 1997: 4).

Secara umum disiplin ilmu entreprenuership berbeda dengan ilmu manajemen, karena kerangka bidang materi manajemen (framework general management course) yang memisahkan antara manajemen dan kepemilikan usaha (business owner). Ilmu entreprenuership mengalami perkembangan, pada masa awal entreprenuership hanya digunakan dalam bidang perdagangan, yang berevolusi pada bidang lain, seperti industri, pendidikan, kesehatan, pemerintah, perguruan tinggi dan lembaga kemasyarakatan lainnya. Dalam konteks tertentu, entreprenuership merupakan suatu kompetisi utama dalam menciptakan perubahan, pembaruan, dan kemajuan.

\section{Entreprenuership dalam Perspektif Alquran}

Ekonomi merupakan salah satu ilmu sosial yang mempelajari aktivitas manusia yang berhubungan dengan produksi, distribusi, dan konsumsi terhadap barang dan jasa. Ilmu ekonomi adalah studi mengenai cara-cara manusia dan masyarakat menentukan/menjatuhkan pilihannya, dengan atau tanpa menggunakan uang untuk menggunakan sumbersumber produktif yang langka yang dapat mempunyai penggunaan-penggunaan alternatif, untuk memprodusir pelbagai barang serta membagikannya untuk dikonsumsi, baik untuk waktu sekarang maupun yang akan datang.

Dasar berusaha dalam ekonomi sangat kuat dalam Alquran dan hadis. Manusia diciptakan di muka bumi ini untuk berusaha/bekerja dalam memenuhi kebutuhan ekonomi. Landasan berusaha ini terdapat dalam surah Al-Balad (90) : 4, dimana Allah Swt. berfirman:

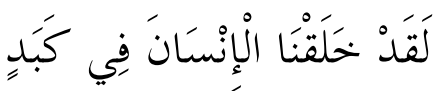

"Sesungguhnya Kami telah menciptakan manusia berada dalam susah payah".

Kata "susah-payah" dalam bahasa arab disebut kabad, memiliki pengertian bahwa manusia diciptakan Allah dalam keadaan yang tidak pernah lepas dari kesulitan (la yanfak min al-masyaq). Sehingga berkerja atau berusaha dalam sektor 
ekonomi merupakan keharusan bagi manusia untuk meningkatkan kesejahteraan dan taraf hidup ekonomi.

Kegiatan ekonomi dalam berbisnis (entreprenuers) merupakan salah satu bentuk pekerjaan yang tidak terlepas dari kehidupan manusia dan dianjurkan dalam Alquran. Alquran menyebut kata entreprenurship atau bisnis dengan padanan kata: at-Tijarah, al-Bai'u, Tadayantum, Isytara, dan FadhlAllah.

Kata At-Tijarah dalam Alquran terdapat sembilan kali (Abdul Baqi, 1993: 193), pengulangan kata tijarah, enam kali diantaranya merujuk pada makna aktifitas ekonomi. (Nuruddin, 2015). Terdapat nilai yang harus dilakukan oleh seorang entreprenuer muslim dalam melakukan kegiatan bisnis. Nilai yang terdapat dalam Alquran menjadi nilai pendorong prilaku entreprenuer, nilai yang terdapat dalam Alquran menjadi falsafah prilaku entreprenuer muslim yang beriman dan bertaqwa, sehingga kegiatan perniagaan, jual beli atau melakukan kegiatan bisnis selalu terarah pada nilai filosofi tersebut. Seperti yang terdapat dalam surah An-Nisa' ayat 29, dimana entreprenuer muslim mengedepankan kemaslahatan (meninggalkan cara yang batil) dan kesepakatan bisnis yang adil ('an taraddin minkum) dalam melakukan kegiatan bisnis.

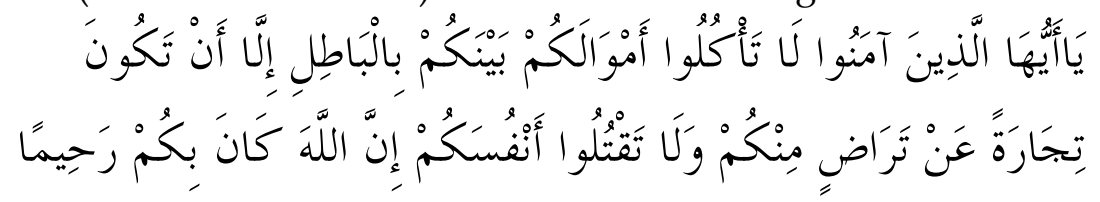

"Hai orang-orang yang beriman, janganlah kamu saling memakan harta sesamamu dengan jalan yang batil, kecuali dengan jalan perniagaan yang berlaku dengan suka sama-suka di antara kamu. Dan janganlah kamu membunuh dirimu; sesungguhnya Allah adalah Maha Penyayang kepadamu" (QS. An Nisa: 29).

Makna tijarah mencakup dua makna, yaitu: pertama, makna pengabdian antara manusia dan penciptanya, ketika manusia melakukan perintah Allah sebagai hamba dengan melakukan ibadah mahdah, digambarkan prilaku manusia tersebut berbisnis dengan Allah, dan orang yang taat terhadap perintah Allah adalah orang mendapatkan keuntungan dalam "tijarah" dengan Allah, dan merupakan bagian dari perniagaan yang terbaik. Begitu juga sebaliknya bila seseorang tidak memanfaatkan petunjuk Allah sebagai pedoman hidup maka 
akan mengalami kerugian dalam tijarah tersebut. Kedua, makna tijarah secara umum, yaitu kegiatan bisnis antara manusia (muamalah). Mengutamaan keadilan dalam berbisnis merupakan nilai yang terdapat dalam tijarah (Al-Baqarah: 282, An-Nisa: 29, an-Nur:37) dimana dijelaskan tentang mekanisme jual beli, utang piutang, sewa menyewa, dan transaksi lainnya. Dalam ayat tersebut juga terdapat nilai akuntansi, kenotariatan dan pembahasan bisnis Islam secara umum.

Motif dari kegiatan entreprenuers merupakan ibadah, ketika seorang entreprenuer melakukan kegiatan bisnis selalu mengingat Allah, menegakkan shalat, membayar zakat. Artinya, setiap prilaku ekonomi yang dilakukan harus terpadu dengan ibadah kepada Allah SWT dan selalu mengingat Allah. Nilai ini menjadi regulasi bagi entreprenuers muslim dalam melakukan kegiatan bisnis agar selalu berbuat kebaikan dan menjauhi prilaku yang merugikan dalam segala aspek kegiatan bisnis. (QS. An Nisa: 29)

Tujuan bisnis dalam Alquran adalah untuk mendapatkan dua keuntungan, yaitu keuntungan duniawi dan ukhrawi. Bisnis dalam Alquran dikategorikan kedalam tiga kelompok, yaitu: bisnis yang menguntungkan, bisnis yang merugi dan pemeliharaan prestasi, reward dan punishment. Dalam hal ini Alquran menyoroti bahwa segala perbuatan manusia tidak akan bisa lepas dari pantauan Allah, sehingga perbuatan yang dilakukan akan memiliki konsekuensi (pahaladosa). (Djakfar, 2007: 146)

Selajutnya, Alquran juga berbicara tentang bai'u, kata bai'u merupakan bagian dari kegiatan transaksi dalam bisnis yang harus dilakukan oleh seorang entreprenuer. Dalam transaksi bisnis Islam, bertujuan untuk meniadakan penipuan, persengketaan atau dampak negatif yang diakibatkan dari suatu transaksi, sehingga dapat memperoleh profit dan benefit yang halal dan berkah. Transaksi jual beli atau akad, merupakan kesepakatan yang dilakukan antara pembeli dan penjual sehingga terjadi suatu transaksi yang diketahui oleh kedua belah pihak sehingga terjadi keadilan dalam transaksi.

Jual beli dibolehkan dalam Alquran dan menjadi istrumen ekonomi bagi entreprenuers dalam mengembangkan bisnisnya. Namum Alquran sangat tegas membedakan antra jual beli dengan bunga. Jual beli adalah trasnsaksi yang terjadi 
untuk memenuhi kebutuhan dan pembeli memiliki kemampuan untuk membeli atau memenuhi kebutuhan tersebut, sedangkan konsep pinjam-meminjam didasari oleh kefakiran, disebabkan ketidak mampuan seseorang memenuhi kebutuhannya, eksploitasi keadaan kefakiran dengan membebankan riba dalam proses pinjaman sangat dilarang dalam Islam, nilai ini terdapat dalam Alquran surah AlBaqarah ayat 275:

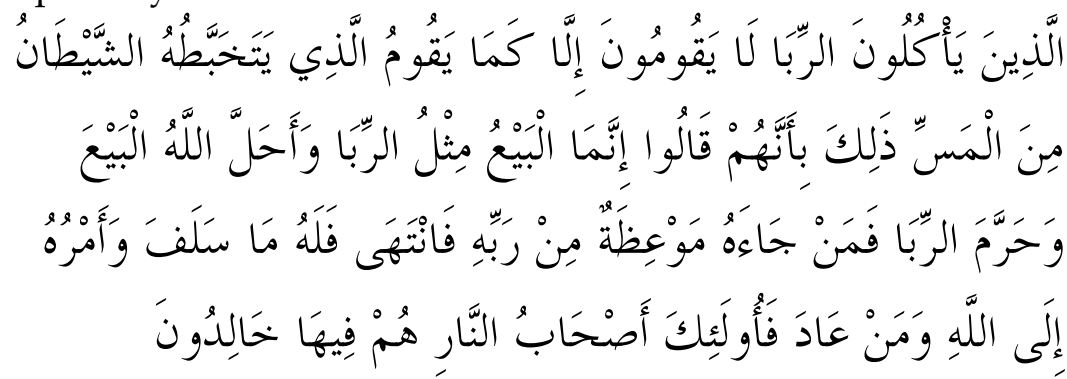

"Orang-orang yang makan (mengambil) riba tidak dapat berdiri melainkan seperti berdirinya orang yang kemasukan syaitan lantaran (tekanan) penyakit gila. Keadaan mereka yang demikian itu, adalah disebabkan mereka berkata (berpendapat), sesungguhnya jual beli itu sama dengan riba, padahal Allah telah menghalalkan jual beli dan mengharamkan riba. Orang-orang yang telah sampai kepadanya larangan dari Tuhannya, lalu terus berhenti (dari mengambil riba), maka baginya apa yang telah diambilnya dahulu (sebelum datang larangan); dan urusannya (terserah) kepada Allah. Orang yang kembali (mengambil riba), maka orang itu adalah penghuni-penghuni neraka; mereka kekal di dalamnya".

Alquran membicarakan istilah bisnis/ekonomi juga dalam kata fadhlun, dan kata turunannya.Bahwa Allah menyediakan karunia bagi manusia yang perlu diupayakan atau diusahakan. (QS. Al Jumuah: 10), Kemudian Alquran berbicara tentang ekonomi dengan istilah "sakhara", yang memiliki arti menundukkan, artinya manusia dapat mengeksploitasi dan menguasai sumber daya ekonomi untuk memenuhi kebutuhan ekonomi dengan cara yang sesuai ketentuan yang terdapat dalam Alquran. Adapun sumber daya yang "ditundukkan" bagi manusia, diantaranya: laut dan sungai dengan segala sumber daya yang ada di dalam laut dan sungai (QS. Ibrahim: 32, An Nahl: 14, dan Al Jatsiyah: 12), 
matahari dan bulan sebagai sumber energi, siang dan malam sebagai waktu yang dimiliki manusia (QS. Ibrahim: 33, Al Ankabut: 61, Luqman: 29, Fathir: 13, dan Az zumar: 5), bumi sebagai sumber daya alam (QS. Al Hajj: 65 dan QS. Luqman: $20)$, sumber daya yang terdapat di langit dan bumi (QS. Al Jatsiyah: 13).

Ayat lain yang secara tegas memuji dan sekaligus memerintahkan manusia untuk berbisnis, baik kegiatan distribusi maupun produksi yang harus dilakukan dan dimajukan oleh umat yang beriman, dan berprilaku sebagai entreprenuers yang dimotivasi oleh iman.

"Laki-laki yang tidak dilalaikan oleh perniagaan dan tidak (pula) oleh jual beli dari mengingati Allah, dan (dari) mendirikan sembahyang, dan (dari) membayarkan zakat. mereka takut kepada suatu hari yang (di hari itu) hati dan penglihatan menjadi goncang" (QS. An Nur: 37)

Penegasan dalam firman tersebut menawarkan kepada manusia agar beraktifitas bisnis, didorong oleh iman, yaitu memberikan keimanan yang tulus kepada Allah dengan diri dan harta benda. Secara implicit pesan ayat ini memberikan penghargaan kepada aktivitas bisnis yang dilakukan dalam kesadaran penuh terhadap aturan Allah Swt. dan berprilaku sebagai entreprenuers sesuai dengan ketentuan dan hukum Allah, dengan melakukan aktivitas ekonomi yang didasarkan pada nilai syariat Allah, akan menjadikan seorang pelaku ekonomi menjadi entreprenuers yang Islami.

Nabi memposisikan perannya sebagai motivator pengembangan semangat entreprenuership, diantaranya Rasulullah S.A.W bersabda: "Sesungguhnya sebaik-baik mata pencarian adalah seorang pedagang (entreprenuer) (HR. Baihaqi). Islam memiliki semangat kewirausahaan yang tinggi. Nabi Muhammad dalam banyak literatur merupakan seorang entreprenuer, begitu juga dengan para sahabat Nabi adalah entreprenuers bahkan berdagang antar negara. Dalam kajian nusantara, Islam masuk ke Indonesia, bahkan Asia Tenggara melalui pedagang-pedagang yang melakukan kegiatan bisnis dan berdakwah. Dengan demikian, Islam mendorong umatnya untuk menjadi entreprenuers untuk memenuhi kebutuhan jasmani dan rohaninya. 
Prilaku entreprenuers yang Islami dibutuhkan dalam dunia usaha, sehingga konsep keadilan yang menjadi prinsip ekonomi Islam dapat terealisasi, entreprenuers yang Islami tidak hanya berorientasi pada gain oriented namun juga untuk kemaslahatan umat. Aturan atau pedoman yang terdapat dalam Alquran dan Hadis akan membangun entreprenurs yang adil dan mengutamakan kemaslahatan umat. Melihat fenomena dalam dunia usaha, pengusaha yang berorientasi pada keuntungan perusahaan akan melakukan strategi-strategi pemasaran yang hanya menguntungkan perusahaan tanpa melihat aspek kemaslahatan umat, baik dari aspek tenaga kerja, upah, pengelolaan sumber daya dan aspek lain.

Entreprenuership digunakan sebagai istilah bagi orangorang yang menanggung risiko kepemilikan bisnis dengan memanfaatkan kesempatan dan bertujuan untuk pertumbuhan dan ekspansi kepentingan dunia dan persiapan akhirat (Abdurrahman, 2013: 143). Prilaku entreprenuership harus dilandasi jiwa yang optimis, dinamis dan kreatif, berusaha menciptakan gagasan-gagasan yang dibutuhkan dan diinginkan oleh konsumen serta memiliki kemampuan untuk berbuat sesuatu yang berguna bagi orang lain/konsumen. Entreprenuers memposisikan dirinya sebagai pemimpin yang berpikiran terbuka yang bergantung pada jaringan kerja dan rencana bisnis.

Islam memandang entreprenuership merupakan bagian kerja, dalam perspektif ekonomi Islam bekerja adalah suatu upaya yang dilakukan seseorang untuk memenuhi kebutuhan jasmani dan rohani. Ajaran Islam sangat mendorong umatnya untuk berperan dalam kegiatan bisnis. Sesuai dengan firman Allah dalam surah At-Taubah :105:

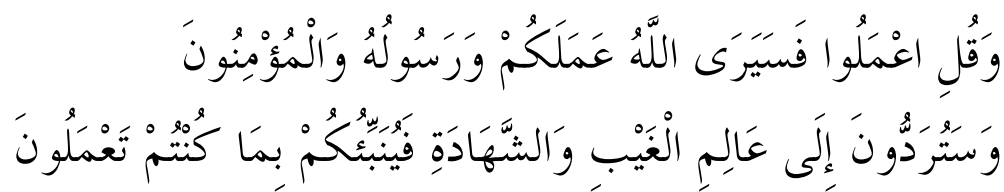

Dan Katakanlah: "Bekerjalah kamu, maka Allah dan RasulNya serta orang-orang mukmin akan melihat pekerjaanmu itu, dan kamu akan dikembalikan kepada (Allah) Yang Mengetahui akan yang ghaib dan yang nyata, lalu diberitakan-Nya kepada kamu apa yang telah kamu kerjakan". 
Perintah bekerja (berusaha) juga terdapat dalam firman Allah dalam ayat yang lain, Allah berfirman: "Apabila kamu telah melaksanakan shalat, maka bertebaranlah kamu di muka bumi dan carilah rezeki Allah dan ingatlah Allah sebanyak-banyaknya agar kamu beruntung". (QS. Al Jumuah: 10)

Hadis Nabi juga memposisikan sebagai motivator pengembangan semangat entreprenuership, diantaranya Rasulullah S.A.W bersabda: "Sesungguhnya sebaik-baik mata pencarian adalah seorang pedagang (entreprenuer)" (HR.Baihaqy). Islam memiliki semangat kewirausahaan yang tinggi. Nabi Muhammad dalam banyak literatur merupakan seorang entreprenuer, begitu juga dengan para sahabat Nabi adalah entreprenuers bahkan berdagang antar negara. Dalam kajian nusantara, Islam masuk ke Indonesia, bahkan Asia Tenggara melalui pedagang-pedagang yang melakukan kegiatan bisnis dan berdakwah. Dengan demikian, Islam mendorong umatnya untuk menjadi entreprenuers untuk memenuhi kebutuhan jasmani dan rohaninya.

\section{Budaya (Etnologi) dan Kegiatan Ekonomi}

Makna kewirausahaan berakar dari kontek sosial budaya, politik dan ekonomi tempat di mana orang belajar dalam menjalankan fungsinya. Etnopedagoi mengeksplorasi dan memberdayakan kearifan lokal dengan penguatan metodeloginya pada penekanan pendekatan kultural dirasakan akan lebih membumi, karena etnopedagogi memandang ilmu pengetahuan atau kearifan lokal sebagai sumber inovasi dan keterampilan yang dapat diberdayakan untuk kesejahteraan masyarakat dan akan memberikan pengayaan yang berarti untuk menunjang tujuan pendidikan nasional yang berjati diri Indoneia (Al Musanna, 2010), termasuk kegiatan ekonomi.

Adat sebagai bagian dari budaya ditinjau dari eksestensinya, hanya dimiliki manusia dalam tiga wujud: (1) Wujud sebagai suatu kompleks gagasan dan konsep hasil pikiran manusia. (2) Wujud sebagai kompleks aktifitas dan (3) wujud budaya berupa benda. Ketiga wujud budaya tersebut mempunyai nilai-nilai yang amat berharga bagi kehidupan. (Koencaraningrat, 1983: 100).

Dalam Kamus Besar Bahasa Indonesia kata adat berarti aturan perbuatan yang lazim diurut dan dilakukan sejak 
dahulu kala, kelakuan yang sudah menjadi kebiasaan. (DEPDIKBUD, 7) Dengan demikian adat bagian dari budaya yang merupakan hasil pikiran, akal budi dari suatu kelompok manusia yang dijadikan sebagai standar kebiasaan dalam masyarakat tertentu yang diatur dalam berbagai ragam dan cara, sehingga disebut dengan adat.

Kebiasan atau adat istiadat mengandung nilai-nilai yang diyakini sebagai norma kehidupan yang mengatur dan mengarahkan cara berpikir, cara merasa, cara bertindak, berorganisasi, bergaul, berekonomi, berkeluarga, mendidik dan seterusnya. (Haq, 2015: 268) Setiap orang yang berakal melakukan sesuatu karena sesuatu itu dipandang bernilai dan cara hidupnya dibentuk oleh nilai-nilai yang dihayatinya, orang yang tidak melakukan perbuatan yang bernilai yang sudah biasa dilaksanakan; dianggap telah mengalami penggeseran nilai.

Budaya mengikat individu secara luas dengan berbagai nilai dan norma, termasuk di dalamnya pola kehidupan masyarakat pada umumnya. Istilah nilai dalam kehidupan sehari-hari sering diperbincangkan oleh masyarakat mengenai maksudnya, tujuan, penghayatan dan pelaksanaannya.

Dalam Kamus Bahasa Indonesia disebutkan salah satu arti nilai adalah sipat-sipat yang penting atau hal-hal yang berguna bagi kemanusian, nilai tradisional yang dapat mendorong pembangunan, sesuatu yang menyempurnakan manusia sesuai dengan hakikatnya. (DEPDIKBUD, 783). Secara garis besar nilai dalam dua bagian yaitu nilai-nilai murni (values of being) dan nilai-nilai memberi (values ofgiving).

Nilai-nilai murni adalah nilai yang ada dalam diri manusia, kemudian berkembang menjadi perilaku dan cara memperlakukan orang lain, termasuk dalam katagori nilai ini: kejujuran, keberanian, cinta damai, keandalan diri, potensi, disiplin, tahu batas, kemanusiaan dan kesesuaian. Sedang nilainilai memberi adalah nilai yang diperaktekkan atau diberikan dan diterima sebanyak yang diberikan, yang masuk dalam nilai kelompok ini ialah setia, dipercaya, hormat, cinta, kasih sayang, peka, tidak egois, baik hati, ramah, adil dan murah hati. (El Mubarok, 2009: 7) Sehingga kebudayaan tidak terlepas dari nilai-nilai yang terdapat dalam masyarakat tertentu. 
Salah satu factor yang mendorong prilaku manusia termasuk dalam berprilaku ekoniomi adalah budaya. Budaya merupakan bagian dari pemikiran, akal budi atau adat istiadat. Secara tata bahasa, kebudayaan diturunkan dari kata budaya cenderung menunjuk pada pola pikir manusia. Pada era globalisasi saat ini prilaku manusia juga tidak terlepas dari budaya atau adat istiadat yang diyakini. Prilaku keseharian manusia merupakan refleksi dari pengetahuan, sikap dan prilaku yang merupakan kebiasaan yang dimiliki dan diwariskan oleh anggota suatu masyarakat.

Kegiatan ekonomi yang dilakukan masyarakat pada saat ini juga berkaitan erat dengan budaya yang dimiliki masing-masing individu. Indonesia kita mengenal kelompok masyarakat tertentu yang memiliki kemampuan dalam bidang ekonomi karena didorong oleh nilai-nilai budaya yang dimiliki, seperti suku Minang, suku Aceh, dan suku Tiong Hoa. Dimana prilaku keseharian merupakan kebiasaan yang diwariskan dari pendahulu, sehingga minat terhadap kegiatan ekonomi khususnya berwirausaha lebih dominan.

Minat masyarakat menjadi entreprenuers berkaitan dengan upaya menambah nilai tambah pada produk, membuka pasar baru, serta memberikan layanan. Membangun nilai-nilai entreprenuership syariah yang berbasis nilai budaya merupakan salah satu cara meningkatkan minat entreprenuership masyarakat. Kajian ini tidak terlepas dari nilai-nilai budaya/adat yang ada. Prilaku keseharian masyarakat merupakan refleksi dari pengetahuan, sikap dan prilaku yang merupakan kebiasaan yang dimiliki dan diwariskan oleh anggota suatu masyarakat yang dituangkan dalam adat istiadat. Sehingga dipandang perlu mengkaji nilai-nilai budaya yang diperkirakan mempengaruhi kurangnya minat, tata kelola dan kesuaian prilaku masyarakat untuk melakukan kegiatan ekonomi (entreprenuership).

\section{Simpulan}

Alquran memiliki teori-teori ekonomi yang tidak habis dipelajari dan diteliti, konsep dan nilai nilai ekonomi yang terdapat dalam Alquran menjadi motivasi dasar prilaku entreprenuers muslim, Alquran yang mengedepankan kemaslahatan umat, keadilan yang mengutamakan etika dalam 
setiap proses prilaku bisnis, menjadi filosofi dasar dalam melakukan kegiatan ekonomi termasuk kegiatan entreprenuership. Dengan menjadikan nilai ekonomi yang terdapat dalam Alquran akan melahirkan entreprenuers muslim yang dapat bersaing dalam era persaingan milenium saat ini.

Budaya menjadi variable penting dalam meningkatkan minat masyarakat mengembangkan industri yang memproduksi nilai tambah pada produk, mampu membuka pasar baru, dan memberikan inovasi kreatif pada setiap proses ekonomi yang dilakukan.

Memadukan nilai filosofis dalam Alquran dan budaya sebagai penggerak minat individu, akan mendorong masyarakat agraris seperti masyarakat Indonesia untuk beralih ke level industri agraris dan industri kreatif yang berasaskan nilai Islam dan melahirkan entreprenuers muslim yang mampu bersaing di era digital milenium.

Gagasan hasil konsep pemikiran manusia dan bentuk aktifitas dalam prilaku ekonomi yang tertuang dalam budaya yang menjadi prilaku turun temurun pada masyarakat bila disesuaikan dengan nilai ekonomi yang terdapat dalam Alquran akan terbangun konsep atau teori tentang entreprenuership syariah.

Entreprenuerships syariah yang sesuai dengan perkembangan yaituentreprenuerships yang memiliki konsep dan ciri-ciri khusus, seperti memiliki kemampuan untuk menciptakan sesuatu yang baru dan berbeda (kreativitas dan inovasi) yang sesuai dengan syariat, mengorganisasikan, menanggung risiko, berorientasi pada kemaslahatan, bergerak pada tujuan duniawi dan ukhrawi, peluang, dan prilaku yang mengedepankan etika. 
Abdiansyah Linge dan Upi Sopiah Ahmad

\section{Daftar Pustaka}

Abdurrahman,Nana Herdiana.Manajemen Bisnis Syariah dan Kewirausahaan (Bandung: Pustaka Setia, 2013)

Al-Musanna, Rasionalitasdan Aktualitas Kearifan Lokal, (Jakarta: Jurnal Pendidikan dan Kebudayaan, Vol. 17 No.5, 2010).

Baqi, Muhammad Fuad Abdul, Al-Mu'jam Al-Mufahrosy, (Bairut: Darul Ma' rifah, 1993)

Departemen Agama RI, Al-Qur'an dan Terjemahannya, Juz 1-30 Edisi Baru (Surabaya: Mekar Surabaya, 2004)

Departemen Pendidikan dan Kebudayaan, Kamus Besar Bahasa Indonesia.

Djakfar,Muhammad.Agama, Etika dan Ekonomi; Wacana Menuju Pengembangan Eknomi Rabbaniyah, (Malang; UIN Malang Press, 2007)

Drucker, P.F. Innovation and Entreprenuership; Practices and Principles, Penerjemah Rusdi Naib. (Jakarta: Gelora Aksara Pratama, 1994),

Elmubarok, Zaim. Membumikan Pendidikan Nilai (Bandung: Alfabeta,2009)

Haq, Abdul.Formulasi Nalar Figh Telaah Kaedah Figh Konseptual (Surabaya: Khalista dan Kaki Lima, 2015)

Koencaraningrat, Persepsi Masyarakat Tentang Kebudayaan, editor Alfian, (Jakarta: Gramedia, 1983)

Nuruddin,Amiur.Bisnis Islam DalamPerspektifAlqurandan AsSunnah, International Conference of Islamic Development (7th ACID) Medan, Sumatera Utara, 12 Juni 2015. 
Entrepreneurship dalam Perspektif Alquran dan Etnologi

Prawirakusumo, Soeharto.Peranan Perguruan Tinggi dalam Menciptakan Wirausahawan. (Jatinangor: PIBI-IKOPIN, 1997)

Schumpeter,J.,Capitalism, Socialism, and Democracy, (London: Allen Unwin, 1934. Di dalam: Suryana, Kewirausahaan, (Jakarta: Salemba Empat, 2013)

Suryana, Kewirausahaan, (Jakarta: Salemba Empat, 2013) 